\title{
KARAKTERISTIK SELF COMPACTING CONCRETE (SCC) TANPA CURING
}

\section{CHARACTERISTIC OF SELF COMPACTING CONCRETE (SCC) WITHOUT CURING}

\author{
Erniati $^{1^{*}}$ \\ *email:erni_nurzaman@yahoo.com \\ ${ }^{1}$ Prodi Teknik Sipil, Fakultas Teknik, Universitas Fajar, \\ Jl. Prof. Abdurrahman Basalamah no. 101, Makassar, 90231
}

\begin{abstract}
ABSTRAK
Self Compacting Concrete (SCC) merupakan salah satu solusi untuk mendapatkan konstruksi beton yang mempunyai ketahanan yang baik. Ketahanan beton diperoleh dengan pemadatan yang baik dengan dilakukan oleh tenaga-tenaga kerja terampil. Namun demikian, salah satu kelalaian yang sering terjadi dilapangan yakni mengabaikan curing pada beton keras setelah pengecoran. Penelitian ini membahas tentang workability beton segar dan sifat mekanik (kuat tekan dan kuat tarik belah) pada SCC tanpa curing. Pengujian workability berdasarkan standar EFNARC. Uji sifat mekanik berdasarkan standar ASTM. Metode pengujian kuat tekan sesuai standar ASTM 39/C 39M - 12a, sedangkan kuat Tarik belah sesuai satndar ASTM C496/C496M-11. Hasil penelitian menunujukkan bahwa SCC tanpa curing memberikan efek penurunan pada kuat tekan pada umur 1, 3, 7, 28, dan 90 hari berturut-turut sebesar 4,11 MPa (16,1\%); 4,90 MPa (13,9\%); 6,64 MPa (13,1\%); dan 6, 72 $\mathrm{MPa}(12,75 \%)$. Kuat tarik belah terjadi penurunan berturut-turut sebesar $0,1 \mathrm{MPa}(3,25 \%)$; $0,26 \mathrm{MPa}(7,99 \%) ; 0,4 \mathrm{MPa}(9,52 \%) ;$ dan $0,39 \mathrm{MPa}(9,16 \%)$.
\end{abstract}

Keywods: Self Compacting Concrete, curing, kuat tekan, kuat tarik belah

\begin{abstract}
Self Compacting Concrete (SCC) is one solution to get concrete construction which it has good resistance. Durability of concrete was obtained by the good concrete compaction to be done by a skilled workforce. However, one of the negligence that often occur in the field ie after casting they was ignoring curing of the hardening concrete. This study discusses the workability of fresh concrete and mechanical properties (compressive strength and splitting tensile strength) on SCC without curing. Testing of the concrete workability based on EFNARC standard. The mechanical properties test based on ASTM standards. The method Compressive strength test based on ASTM standards 39 / C 39M - 12a, whereas splitting tensile strength accordance standard ASTM C496 / C496M-11. The results of the study indicate that the SCC without curing effect on the reduction in compressive strength at ages 1, 3, 7, 28, and 90 days in a row at $4.11 \mathrm{MPa}$ (16.1\%); $4.90 \mathrm{MPa}$ (13.9\%); $6.64 \mathrm{MPa}$ (13.1\%); and 6, $72 \mathrm{MPa}(12.75 \%)$. Splitting tensile strength decreased respectively by 0.1 $\operatorname{MPa}(3.25 \%) ; 0.26 \mathrm{MPa}(7.99 \%) ; 0.4 \mathrm{MPa}(9.52 \%)$; and $0.39 \mathrm{MPa}(9.16 \%)$.
\end{abstract}

Keywods:: Self Compacting Concrete, curing, kuat tekan, kuat tarik belah

\section{PENDAHULUAN}

Teknologi beton saat ini berkembang sangat pesat. Penelitian yang inovatif dilakukan untuk mendapatkan sesuatu yang baru sebagai upaya meningkatkan kualitas beton bermunculan. Semua yang dilakukan para peneliti dimaksudkan untuk menjawab permasalahan yang timbul dalam penggunaan bahan dalam pencampuran beton serta mengatasi kendala-kendala yang sering terjadi dalam pelaksanaan pekerjaan di 
lapangan.

Self Compacting Concrete (SCC) merupakan hasil riset di Jepang pada awal tahun 80 -an. Beton SCC merupakan beton yang inovatif yang tidak memerlukan getaran ataupun alat pemadat karna baton SCC dapat memadat sendiri. Hal ini karna beton SCC dapat mengalir di bawah beratnya sendiri, sehingga dapat mempermudah dalam pengerjaan beton terutama pada struktur dengan menggunakan tulangan kompleks, karna beton SCC dapat mengalir dan mengisi setiap ruang kosong dari cetakannya (Efnarc,2005). Beton segar SCC memiliki fluiditas tinggi yang dapat mengalir dan mengisi ruang-ruang dalam cetakan dengan sedikit atau tanpa proses getaran (Okamura, H dan Ouchi, M, 2003).

Pembangunan konstruksi beton yang mempunyai ketahanan membutuhkan pemadatan yang baik, dimana pemadatan tersebut dilakukan oleh tenaga-tenaga kerja terampil. Semakin berkurangnya tenaga-tenaga kerja terampil dalam dunia konstruksi mengakibatkan beton kadang-kadang tidak terpadatkan dengan baik sehingga menurunkan mutu pekerjaan konstruksi. Okamura, H dan Ouchy, M (2003), salah satu pemecahan untuk memperoleh struktur beton yang memiliki ketahanan yang baik adalah dengan menggunakan SCC. SCC merupakan konsep inovatif teknologi beton yang efektif dan efisien, dimana SCC memiliki karakter memiliki sifat kecairan (fluidity) yang tinggi sehingga mampu mengalir dan mengisi ruang-ruang di dalam cetakan dengan sedikit/tanpa proses pemadatan. Hal ini dapat mengurangi waktu proses pemadatan karena tingkat kecairan yang tinggi, sehingga SCC mampu diangkat dan dibawa dengan mudah melalui pompa ke tingkat yang tinggi pada pengecoran bangunan berlantai banyak serta pada struktur yang memiliki tulangan sangat padat.

Erniati dkk $(2014,2015)$ telah meneliti tentang SCC yang mengguakan air laut. Dalam penelitiannya telah mengkaji kuat tekan dan mikrostruktur. Dari hasil penelitiannya bahwa kuat Kenaikan kuat tekan SCC yang menggunakan air laut dan air tawar mengalami perbedaan yang paling signifikan pada umur dini yakni umur 1 dan 3 hari. Ini terjadi karena air laut mempercepat terbentuknya tobermorite (CSH) sehingga ikatan matriks dengan agregat semakin kuat. Selain itu friedel's salt yg terbentuk mengisi pori sehingga mikrostruktur lebih padat. Peningkatan kepadatan mikrostruktur sejalan dengan peningkatan sifat mekanik (kuat tekan dan kuat tarik belah) serta penurunan ukuran pori dan porositas.

Terkait dengan metode SCC merupakan teknologi yang sangat efektif dan efisien, namun jika dilapangan terjadi kelalaian dalam pelaksanaan khususnya setelah pengecoran para pekerja lalai dalam pemeliharaan beton maka kualitas mutu yang diharapkan akan terjadi efek yang tidak diinginkan. Unuk itulah dalam penelitian ini akan dikaji mengenai karakteristik SCC tanpa ada pemeliharaan/curing pada beton mengeras.

\section{METODE PENELITIAN}

Metode penelitian yang digunakan adalah meteode eksperimental yang dilaksanakan di laboratorium. Adapun bahan, peralatan dan desain pencampuran dan ekperimental dijelaskan sebagai berikut :

\section{Bahan}

Bahan yang digunakan dalam penelitian ini adalah semen tipe Portland Cement Composite (PCC), agregat kasar/batu pecah (ukuran maksimum $20 \mathrm{~mm}$ ), agregat halus/pasir lokal (ukuran maksimum 4,75) dan superplasticier jenis A ViscoCrete-3115. $144 \quad$ Jurnal Ilmiah Techno Entrepreneur Acta, Vol.1 No.2, Oktober 2016 


\section{Peralatan}

Alat yang digunakan dalam penelitian ini adalah mesin pencampur bahan (mixer), cetakan berbentuk silinder diameter $10 \mathrm{~cm}$ dan tinggi $20 \mathrm{~cm}$, timbangan, oven, flow table, flow cone, penggaris, Universal Testing Machine (UTM).

\section{Mix Desain dan Ekperimental Prosedur}

Metode yang digunakan dalam desain SCC adalah metode The European Federation of Specialist Chemicals and Concrete Constructions Systems (EFNARC). Dalam design digunakan rasio volume air / semen sama dengan 1.1 atau sama dengan factor air semen 0.35. SCC-FF merupakan nama yang diberikan pada beton yang memadat sendiri dengan curing, dan untuk SCC-FA merupakan nama yang diberikan pada beton yang memadat sendiri tanpa perawatan/ curing.

Pencampuran beton SCC dilakukan setelah pemeriksaan agregat baik kasar maupun halus dilakukan sesuai dengan standar American society For Testing Material (ASTM) . Setelah memeuhi syarat material penyusun dilakukan pencampuran dan pemeliharaan beton dilaksanakan di Laboratorium Teknik Sipil Universitas Fajar. Workability beton segar diamati dengan menggunakan Slump cone untuk menentukan slump flow dan T500 yang diukur sebagai persyaratan apakah memenuhi sebagai SCC atau tidak. Sampel kuat tekan menggunakan benda uji berbentuk silinder dengan ukuran $10 \mathrm{~mm} \mathrm{x}$ $20 \mathrm{~mm}$. Pengujian kuat tekan dan kuat tarik belah dilakukan pada umur 1 hari,3 hari, 7 hari, 28 hari dan 90 hari dengan masing-masig 3 sampel yang mewakili dari 3 sampel yang diuji. Penelitian uji mekanik yang dilakukan dalam penelitian ini ada dua yaitu kuat tekan dan tarik belah. Metode pengujian kuat tekan sesuai standar ASTM 39/C 39M - 12a, sedangkan kuat Tarik belah sesuai satndar ASTM C496/C496M-11, 2011. Pengujian sifat mekanik dilakukan di Laboratorium Teknik Sipil Politeknik Negeri Ujung Pandang.

\section{HASIL DAN PEMBAHASAN}

\section{Agregat}

Pengujian Agregat baik agregat halus dan agregat kasar dilakukan dilaboratorium berdasarkan standar ASTM. Hasil pengujian material agregat diperoleh kteristik agregat halus dan agregat kasar telah memenuhi kriteria sebagai material penyusun beton. Hasil pengujian agregat halus dan agregat kasar dapat dilihat berturut-turut pada Tabel 1 dan Tabel 2.

Tabel 1. Hasil Pemeriksaan Karakteristik Agregat Halus (Pasir)

\begin{tabular}{|c|c|c|c|c|}
\hline No & Karakteristik Agregat & ASTM & $\begin{array}{c}\text { Hasil } \\
\text { Pemeriksaan }\end{array}$ & Keterangan \\
\hline 1 & Analisa Saringan & & Gradasi Zona 2 & Memenuhi \\
\hline 2 & Modulus Kehalusan & $2,5-3,2$ & 2,54 & Memenuhi \\
\hline 3 & $\begin{array}{l}\text { Berat Jenis: } \\
\text { a. BJ Curah } \\
\text { b. BJ Kering Permukaan } \\
\text { c. BJ Semu }\end{array}$ & $\begin{array}{l}1,6-3,3 \\
1,6-3,3 \\
1,6-3,3\end{array}$ & $\begin{array}{l}2,53 \\
2,56 \\
2,61\end{array}$ & $\begin{array}{l}\text { Memenuhi } \\
\text { Memenuhi } \\
\text { Memenuhi }\end{array}$ \\
\hline 4 & Absorpsi & Maks $2 \%$ & 1,21 & Memenuhi \\
\hline 5 & $\begin{array}{l}\text { Berat Volume : } \\
\text { a. Kondisi Lepas } \\
\text { b. Kondisi Padat }\end{array}$ & $\begin{array}{l}1,4-1,9 \mathrm{~kg} / \mathrm{ltr} \\
1,4-1,9 \mathrm{~kg} / \mathrm{ltr}\end{array}$ & $\begin{array}{l}1,67 \\
1,81 \\
\end{array}$ & $\begin{array}{l}\text { Memenuhi } \\
\text { Memenuhi }\end{array}$ \\
\hline
\end{tabular}

Jurnal Ilmiah Techno Entrepreneur Acta, Vol.1 No.2, Oktober 2016 


\begin{tabular}{|c|l|c|c|c|}
\hline 6 & Kadar Air & $2 \%-5 \%$ & 2,73 & Memenuhi \\
\hline 7 & Kadar Lumpur & Maks 5\% & 2,15 & Memenuhi \\
\hline 8 & Kadar Organik & $<$ No. 3 & No. 1 & Memenuhi \\
\hline
\end{tabular}

Tabel 2. Hasil Pemeriksaan Karakteristik Agregat Kasar (Batu Pecah)

\begin{tabular}{|c|c|c|c|c|}
\hline No. & Karakteristik Agregat & ASTM & $\begin{array}{c}\text { Hasil } \\
\text { Pemeriksaan }\end{array}$ & Keterangan \\
\hline 1 & Analisa Saringan & & Gradasi zone 2 & Memenuhi \\
\hline 2 & Modulus Kehalusan & $5,5-8,5$ & 6,72 & Memenuhi \\
\hline 3 & $\begin{array}{l}\text { Berat Jenis : } \\
\text { a. BJ Curah } \\
\text { b. BJ Kering Permukaan } \\
\text { c. BJ Semu }\end{array}$ & $\begin{array}{l}1,6-3,3 \\
1,6-3,3 \\
1,6-3,3\end{array}$ & $\begin{array}{l}2,58 \\
2,64 \\
2,74\end{array}$ & $\begin{array}{l}\text { Memenuhi } \\
\text { Memenuhi } \\
\text { Memenuhi }\end{array}$ \\
\hline 4 & Absorpsi & $0,2 \%-4 \%$ & 2,32 & Memenuhi \\
\hline 5 & $\begin{array}{l}\text { Berat Volume : } \\
\text { a. Kondisi Lepas } \\
\text { b. Kondisi Padat }\end{array}$ & $\begin{array}{l}1,4-1,9 \mathrm{~kg} / \mathrm{ltr} \\
1,4-1,9 \mathrm{~kg} / \mathrm{ltr}\end{array}$ & $\begin{array}{l}1,60 \\
1,71\end{array}$ & $\begin{array}{l}\text { Memenuhi } \\
\text { Memenuhi }\end{array}$ \\
\hline 6 & Kadar Air & $0,5 \%-2 \%$ & 1,37 & Memenuhi \\
\hline 7 & Kadar Lumpur & $0,2 \%-1 \%$ & 0,70 & Memenuhi \\
\hline 8 & Keausan & $15 \%-50 \%$ & 32,22 & Memenuhi \\
\hline
\end{tabular}

\section{Slump flow dan T500}

Pengukuran Slump Flow dilakukan untuk mengetahui kelecakan (workability) adukan beton SCC. Kelecakan adukan beton SCC merupakan ukuran dari tingkat kemudahan campuran untuk diaduk, diangkut, dituang dan dipadatkan tanpa menimbulkan pemisahan bahan penyusun beton (segregation). Tingkat kelecakan ini dipengaruhi oleh komposisi campuran, kondisi fisik dan jenis bahan pencampurnya. Hasil pengujian slump flow untuk T50 yaitu 2,45 detik, 2,43 detik, dan 2,52 detik. Dengan demikian hasil nilai rata-rata sebesar 2,47 detik, dan telah memenuhi spesifikasi dari EFNARC yaitu $2-5$ detik. Pengujian slump flow pada penelitian ini dilakukan sebanyak tiga kali. Hasil pengujian slump flow untuk beton SCC secara berturutturut yaitu sebesar $720 \mathrm{~mm}, 717,5 \mathrm{~mm}$ dan $730 \mathrm{~mm}$ dengan rata-rata yaitu 722,5 $\mathrm{mm}$ dan telah memenuhi batas syarat nilai slump test yaitu $600-800 \mathrm{~mm}$. Dari hasil pengujian slump flow ini juga menunjukkan adukan campuran beton SCC telah tercampur dengan merata dan sempurna dan tidak lagi terjadi segregasi (pemisahan kerikil) dan bleeding (naiknya air kepermukaan).

\section{Kuat Tekan dan Kuat Tarik Belah}

Kuat tekan beton adalah besarnya beban per satuan luas, dimana penyebab benda uji beton hancur bila dibebani dengan gaya tekan tertentu yang dihasilkan oleh mesin tekan. Kuat tekan beton merupakan sifat terpenting dalam kualitas beton dibanding dengan sifat-sifat lain. kuat tekan beton ditentukan oleh pengaturan dari perbandingan semen, agregat kasar dan halus, air dan berbagai jenis campuran. Faktor air semen merupakan faktor utama dalam menentukan kekuatan beton. Semakin rendah faktor air semen, semakin tinggi kekuatan desaknya. Namun kelebihan air meningkatkan kemampuan kemudahan dalam pengerjaan beton (workability) akan tetapi menurunkan kekuatan. Dengan memanfaatkan teknologi beton SCC, maka factor air semen yang kecil akan memperoleh kuat tekan yang tinggi dengan tetap workability yang baik. 
Metode uji belah silinder (spliting tensile strength) yang umumnya memberikan hasil yang lebih baik dan lebih mencerminkan kuat tarik sebenarnya. Nilai pendekatan yang diperoleh dari hasil pengujian berulang kali kuat tarik $T=0,50-0,60$ $\sqrt{f^{\prime} c}$ (Istimawan D, 1994). Pasal 11.5 SNI-03-2847 (2002) nilai kuat tarik beton bila dihubungkan dengan kuat tekannya adalah $\mathrm{T}=0,7 \sqrt{f^{\prime} c}$ (Mpa). Pengujian kuat tekan dan kuat tarik belah beton SCC yang curing dan tanpa curing dilakukan pada umur 3 hari, 7 hari, 28 hari dan 90 hari. Hasil pengujian dapat dilihat pada Tabel 3.

Tabel 3. Hasil Pengujian Kuat tekan dan Kuat Tarik Belah SCC

\begin{tabular}{|c|c|c|c|c|c|c|c|}
\hline \multirow{2}{*}{ No. } & Umur & \multicolumn{3}{|c|}{ SCC dengan Curing } & \multicolumn{3}{c|}{ SCC tanpa Curing } \\
\cline { 3 - 8 } & (hari) & $\begin{array}{c}\text { Nama } \\
\text { Sampel }\end{array}$ & $\begin{array}{c}\text { Kuat tekan } \\
\text { rata-rata } \\
\text { (MPa) }\end{array}$ & $\begin{array}{c}\text { Kuat Tarik } \\
\text { Belah (MPa) }\end{array}$ & $\begin{array}{c}\text { Nama } \\
\text { Sampel }\end{array}$ & $\begin{array}{c}\text { Kuat tekan } \\
\text { rata-rata } \\
\text { (MPa) }\end{array}$ & $\begin{array}{c}\text { Kuat Tarik } \\
\text { Belah } \\
\text { (MPa) }\end{array}$ \\
\hline 1 & 1 & SCC-FF-1 & 9,11 & 1,88 & SCC-FA-1 & 9,11 & 1,88 \\
\hline 2 & 3 & SCC-FF-3 & 25,55 & 2,93 & SCC-FA-3 & 21,44 & 2,83 \\
\hline 3 & 7 & SCC-FF-7 & 35,22 & 3,30 & SCC-FA-7 & 30,32 & 3,04 \\
\hline 4 & 28 & SCC-FF-28 & 50,58 & 4,20 & SCC-FA-28 & 43,94 & 3,80 \\
\hline 5 & 90 & SCC-FF-90 & 52,69 & 4,21 & SCC-FA-90 & 45,97 & 3,82 \\
\hline
\end{tabular}

Kuat tekan yang direnacanakan sebesar 50 Mpa pada penelitian ini sesuai target, ini terlihat seperti pada Tabel 3 yakni pada umur 28 hari : 50,58 Mpa. Namun demikian jika beton SCC tidak dilakukan pemeliharaan dengan merawatnya maka terjadi penurunan sebesar 6,64 Mpa $(13,13 \%)$, begitupun dengan kuat tarik belah, terjadi penurunan sebesar $0,4 \mathrm{MPa}(9,52 \%)$ dari target yang direncanakan.

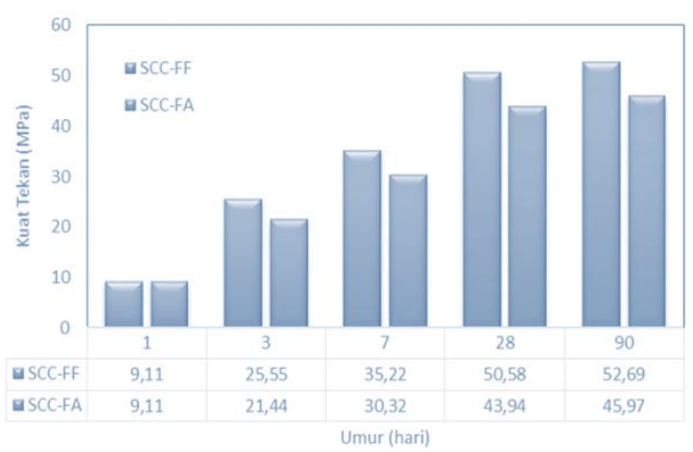

(a)

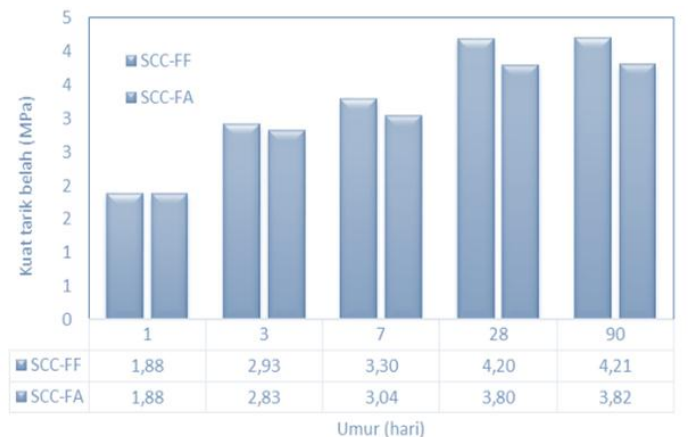

(b)

Gambar 1. Hubungan kuat tekan dan kuat tarik belah dengan umur pada SCC-FF \& SCC-FA

Gambar 1.a menujukkan hubungan kuat tekan dan umur SCC-FF dan SCC-FA. Kuat tekan meningkat seiring dengan bertambahnya umur baik pada SCC-FF maupun SCC-FA. Disamping itu terlihat pada Gambar 1, terjadinya penurunan kuat tekan pada SCC-FA sejak umur 3 hari, 7, 28 sampai dengan umur 90 hari berturut-turut sebesar 4,11 $\mathrm{MPa}(16,1 \%) ; 4,90 \mathrm{MPa}(13,9 \%) ; 6,64 \mathrm{MPa}(13,1 \%)$; dan 6, $72 \mathrm{MPa}(12,75 \%)$.

Gambar 1.b menujukkan hubungan kuat tarik belah dan umur SCC-FF dan SCCFA. Kuat tarik belah meningkat seiring dengan bertambahnya umur baik pada SCC-FF maupun SCC-FA. Disamping itu terlihat pada Gambar 1, terjadinya penurunan kuat tarik belah pada SCC-FA sejak umur 3 hari, 7, 28 sampai dengan umur 90 hari berturutturut sebesar 0,1 $\mathrm{MPa}(3,25 \%)$; 0,26 $\mathrm{MPa}(7,99 \%) ; 0,4 \mathrm{MPa}(9,52 \%)$; dan 0,39 $\mathrm{MPa}$ $(9,16 \%)$.

Penurunan kuat tekan dan kuat tarik belah terjadi pada SCC tanpa curing ini disebabkan karena adanya proses hidrsi yang tidak optimal. Sebagaimana hasil 
penelitian yang menjelaskan bahwa Beton yang mengalami proses hidarasi yang optimal maka kepadatan beton tinggi dalam hal ini porositas rendah, ikatan matriks dengan agregat optimal sehingga mengakibatkan mikrostruktur pada beton SCC semakin padat (Erniati, 2014; 2015).

\section{PENUTUP}

\section{Kesimpulan}

Desain pencampuran Self Compacting Concrete dengan menggunakan semen PCC, batu pecah dengan ukuran maksimum $20 \mathrm{~mm}$, rasio volume air persemen $=1.1$ menghasilkan workability yang baik dan memenuhi standar EFNARC. Disamping itu adukan campuran beton SCC telah tercampur dengan merata dan sempurna dan tidak terjadi segregasi (pemisahan kerikil) dan bleeding (naiknya air kepermukaan).

SCC tanpa curing memberikan efek penurunan pada kuat tekan pada umur 1, 3, 7, 28, dan 90 hari berturut-turut sebesar 4,11 MPa (16,1\%); 4,90 MPa (13,9\%); 6,64 MPa $(13,1 \%)$; dan 6, $72 \mathrm{MPa}(12,75 \%)$. Kuat tarik belah terjadi penurunan berturut-turut sebesar 0,1 MPa (3,25\%); 0,26 MPa (7,99\%); 0,4 MPa (9,52\%); dan 0,39 MPa (9,16\%). Saran

Penelitian ini masih perlu dilanjutkan dengan merekayasa metodenya seperti terjadi dilapangan yakni sampel beton SCC disimpan diluar ruangan yang kena terik matahari dengan divariasikan curing 1 hari, 3 hari, 7, dan 28 hari.

\section{Referensi}

ASTM C39/C39M - 12a, Standard Test Method for Compressive Strength of Cylindrical Concrete Specimens, October 2012.

ASTM C496/C496M-11,2011 Standard Test Method for Splitting Tensile Strength of Cylindrical Concrete Specimen, August 2011.

EFNARC (2005). The European Guidelines for Self-Compacting Concrete: Specification, Production and Use, UK (www.efnarc.org), May, 2005.

Dipohusodo Istimawan. 1994. Struktur Beton Betulang, Gramedia

Erniati, M. Wihardi Tjaronge, Rudy Djamaluddin, Victor Sampebulu. 2014. Microstructure Characteristics of Self Compacting Concrete using Sea Water, International journal of Applied Engineering Research: Vol 9. Number 22, pp 18087-18095.

Erniati, M.Wihardi.Tjaronge, Rudy Djamaluddin, Victor Sampebulu. 2015. Compressive Strength and Slump Flow of Self Compactig Concrete Uses Fresh Water and Sea Water, ARPN Journal of Engineering and Applied Sciences: Vol 10. Number 6, pp 2373-2377.

Erniati, M.Wihardi.Tjaronge, Rudy Djamaluddin, Victor Sampebulu. 2015. Porosity and Microstructure Phase of Self Compacting Concrete Using Sea Water as Mixing Water and Curing, Advanced Material Research, Vol. 1119, pp 647-651.

Erniati, M.Wihardi.Tjaronge, Zulharnah, Ulfa Ria Arvan. 2015. Porosity, pore size and compressive strength of self compacting concrete, Procedia Engineering, Vol 125, pp $832-837$.

Okamura, H. and Ouchi, M. 2003. Self-Compacting Concrete, Journal of Advanced Concrete Technology, Vol.1, No.5 - 15, April 2003.

SNI 03-2847-2002. Tata Cara Perhitungan Struktur Beton untuk Bangunan Gedung, Beta version, Bandung. 


\section{Aturan Penulisan Artikel Ilmiah Hasil Penelitian pada Jurnal Ilmiah \\ "TECHNO ENTREPRENEUR ACTA" (Jurnal-TEA)}

A. Judul

1. Tema tulisan adalah tentang keteknikan khususnya pada bidang spesifik divisi teknik Mesin, Arsitektur, Sipil, Elektro dan teknik Kimia/kimia Science, baik untuk tujuan pengembangan keilmuan maupun untuk pengembangan masyarakat dalam rangka pembentukan pribadi yang entrepreneur;

2. Judul artikel maksimal 15 kata tanpa singkatan dan termasuk kata bantu, ditulis dalam Bahasa Indonesia huruf kapital, dan bagian bawah judul ditulis kembali dalam bahasa Inggris Italic;

3. Nama Penulis terdiri dari penulis utama, penulis kedua dan seterusnya jika ada;

4. Penulis utama diberi tanda exp."1" di depan bagian atas nama, penulis kedua tanda exp."2" dan seterusnya;

5. Wajib manuliskan alamat Email penulis utama;

6. Asal Instansi penulis utama, penulis kedua dan seterusnya;

7. Jenis huruf Times New Roman pont 13 untuk judul dan pont 11 untuk nama dan identitas.

B. Abstrak

1. Abstrak ditulis dalam Bahasa Bahasa Indonesia dan Inggris rata tengah;

2. Abstrak ditulis dalam 1 paragraf

3. Isi abstrak terdiri latar belakang, tujuan, metode, hasil, pembahasan dan kesimpulan atau rekomendasi dan serta kata kunci;

4. Abstrak ditulis pada bagian tengah layar ketikan dengan ketikan masuk kedalam kiri dan kanan masing-masing 1,5 cm serta rata kiri dan kanan;

5. Pada bagian bawah isi abstrak dilengkapi dengan kata kunci dengan jumlah kata kunci 5 sampai 7 dan bukan merupakan kata bantu;

6. Jumlah kata dalam abstrak antara 200 sampai 250 termasuk kata bantu;

7. Seluruh isi abstrak dan kata kunci ditulis dengan jenis huruf Times New Roman pont 11.

C. Sistimatika Artikel

1. Judul (Indonesia dan Inggris), nama penulis, dibubuhi angka 1 untuk penulis utama, angka 2 untuk penulis kedua dan seterusnya;

2. Email wajib dicantumkan bagi penulis utama dan dibubuhi tanda “*”, untuk korespondensi; 1

3. Abstrak Indonesia dan Inggris dan masing-masing memiliki kata kunci;

4. Pendahuluan (berisi tentang argumentasi/alasan yang melatar belakangi sehingga penelitian tersebut dilakukan dan melahirkan artikel termasuk teori yang mendukung);

5. Metode (pendekatan yang dilakukan untuk memecahkan masalah dalam jurnal hasil penelitian, termasuk sampling, waktu, tempat, dan data penunjang terkait);

6. Hasil (berisi tentang data yang diperoleh untuk menjawab dan memecahkan masalah yang menjadi fokus riset/ kajian yang dilakukan);

7. Pembahasan (berisi tentang ulasan atau hasil kajian ilmiah penulis yang bertujuan untuk menjawab pemasalahan); 
8. Kesimpulan/rekomendasi (berisi tentang pernyataan-pernyataan yang menjawab tujuan dari penelitian);

9. Ucapan terima kasih jika penelitian merupakan hasil kerjasama atau terdapat pihak yang berperan penting dalam pelaksanaan dan keberhasilan penelitian yang dilakukan, seperti bantuan dana, informasi, data, sarana dan prasarana, dan lain-lain);

10. Referensi (referensi ditulis sumber-sumber yang menjadi rujukan penulis dalam melakukan penelitian dan penulisan jurnal, baik sumber berupa buku, jurnal, prosiding, atau melalui akses media Internet on line (bukan blok, wikipedia dan lain-lain sejenis);

11. Referensi minimal 10 dan maksimal 25 skala prioritas, dibuat dengan format bersusun abjad runtut sesuai sitasi yang dibuat;

12. Referensi sedapat mungkin disusun mengikuti teknik penulisan referensi internasional format Zotero; End Note atau Mendelay dan sejenis.

D. Ketentuan Lain

1. Jumlah terbitan 2 nomor setiap tahun, yakni setiap Bulan April dan Bulan Oktober tahun berjalan;

2. Naskah artikel yang memenuhi syarat dapat diterima oleh redaksi setiap hari kerja, atau mengirim langsung keredaksi via pos atau melakukan registrasi pada media on line di website: www.tea.unifa.ac.id;

3. Jurnal berbentuk cetakan/hard copy dan on line di website: www.tea.unifa.ac.id;

4. Data tabel, dibuat tertutup atas-bawah dan terbuka kiri-kanan, judul tabel ditulis dibagian atas spasi 1 rata kiri selurus dengan kiri tabel;

5. Data gambar, grafik, foto dan sejenisnya, judul gambar ditulis di bawah rata kiri selurus dengan kiri gambar;

6. Kesimpulan dibuat dalam bentuk narasi 1 paragraf runtut sesuai urutan tujuan dan tidak diberi nomor;

7. Seluruh isi naskah ditulis dengan huruf Times New Roman pont 12;

8. Panjang naskah antara 6 sampai dengan 12 halaman dan jumlah halaman isi harus genap termasuk referensi;

9. Naskah ditulis dalam format 2 (dua) kolom, spasi 1 (satu);

10. Untuk lebih jelas terlampir contoh (template) artikel dimaksud;

11. Naskah diketik di atas kertas A4 spasi 1 (satu) dengan lay out marging kiri 1,0 $\mathrm{cm}$, kanan $1,0 \mathrm{~cm}$, atas $1,5 \mathrm{~cm}$ dan bawah $1,0 \mathrm{~cm}$;

12. Naskah yang memenuhi syarat, hard copy sebanyak 3 (tiga) rangkap dalam amplop coklat, dikirim ke redaksi Jurnal-TEA Kampus UNIFA Alamat Fakultas Teknik Universitas Fajar, Makassar; Alamat: Gedung C Lantai 1, Ruang 104, Jl. Prof. Abdurahman Basalamah No.101 Telp.: (0411) 447508-459938; Fax. (0411) 441119, soft copy pada E-mail: tea@unifa.ac.id atau Ismailmz3773@gmail.com; website www.tea.unifa.ac.id ;

13. Naskah dibuat dalam file microsoft word;

14. Bersediah membayar kontribusi sebesar Rp. 200.000,- setiap artikel yang disetujui untuk diterbitkan;

15. Setiap penulis utama akan mendapat hard copy 2 (dua) exemplar sesuai volume dan nomor issue dan nomor artikel yang dimuat. 